\title{
PENINGKATAN KONSENTRASI DAN HASIL BELAJAR KOMPOSISI FUNGSI DAN FUNGSI INVERS DENGAN PEMBELAJARAN KOOPERATIF TYPE NUMBERED HEAD TOGETHER (NHT) PADA KELAS XI TP 2
}

Oleh :

Nurlaila Mahmudah

SMK N 3 Yogyakarta

email: laila_nur10@yahoo.com

\begin{abstract}
Abstrak
Penelitian ini bertujuan untuk: 1) mendeskripsikan pelaksanaan pembelajaran yang mampu meningkatkan konsentrasi dan hasil belajar; 2) meningkatkan konsentrasi belajar; dan 3) mengetahui besarnya peningkatan hasil belajar peserta didik dengan diterapkanya type pembelajaran Numbered Head Together (NHT) pada kompetensi Fungsi Komposisi dan Fungsi Invers di kelas XI TP 2 SMK N 3 Yogyakarta.

Setting dan subyek penelitian ini adalah peserta didik kelas XI TP 2 yang berjumlah 32 siswa. Data tentang konsentrasi dikumpul dengan instrumen lembar observasi dan hasil belajar diambil dari hasil tes ahir siklus. Data dianalisis dengan menggunakan teknik analisis diskriptif kualitatif. Indikator keberhasilan dari penelitian adalah 100\% siswa mencapai kriteria BAIK untuk indikator konsentrasi dan untuk indikator hasil belajar 75\% peserta didik minimal mencapai KKM.

Hasil penelitian pada pra tindakan skor konsentrasi 6,6\% dengan kriteria baik dan hasil belajar diatas KKM sebesar 41\%. Skor konsentrasi pada siklus I naik menjadi 50\% mencapai kriteria baik diikuti kenaikan hasil belajar sebesar 50\% mencapai nilai diatas KKM. Pada siklus II pencapaian skor konsentrasi dengan kriteria baik meningkat drastis menjadi 100\% dan hasil belajar sebesar $91 \%$ diatas KKM.
\end{abstract}

Kata Kunci : Numbered Head Together (NHT), Konsentrasi, Hasil Belajar.

\section{PENDAHULUAN}

Tercapai atau tidaknya tujuan pendidikan sangat ditentukan oleh bagaimana proses belajar yang dialami oleh para peserta didik dilaksanakan. Dengan kata lain dari keseluruhan proses pendidikan di sekolah, kegiatan belajar peserta didik merupakan kegiatan yang paling pokok dan perlu mendapatkan perhatian lebih.

Kemampuan seseorang untuk berkonsentrasi pada saat belajar atupun pada saat mengerjakan tugas - tugas sangat penting. Menurut Muhibbin Syah (2005: 136), seseorang menaruh minat besar terhadap matematika akan memusatkan perhatianya lebih banyak daripada siswa lainya. Kemudian karena pemusatan perhatian terhadap materi yang intensif itulah akan mendorong siswa untuk belajar lebih giat dan ahirnya mencapai prestasi yang diinginkan. Handy Susanto juga mengatakan bahwa anak akan dikatakan berkonsentrasi pada pelajaran jika dia bisa memusatkan perhatian pada apa 
yang dipelajarinya, karena dengan berkonsentrasi anak tidak mudah mengalihkan perhatian pada masalah lain diluar yang dipelajarinya (2006: 47)

Rendahnya hasil belajar tidak salalu disebabkan karena rendahnya kemampuan melainkan dari kurangnya konsentrasi peserta didik pada saat proses pembelajaran berlangsung. Penyebab sulitnya peserta didik berkonsentrasi tidak selalu berasal dari peserta didik itu sendiri melainkan dari kurangnya ketrampilan pendidik dalam mengelola proses pembelajaran. Pemilihan type pembelajaran yang kurang dapat melayani kebutuhan peserta didik secara keseluruhan, berakibat pembelajaran terkesan monoton dan kurang variatif sehingga membuat peserta didik kurang tertarik dan tidak aktif sehingga sulit untuk konsentrasi.

Agar lebih terarah dan variatif dalam melaksanakan proses pembelajaran, peneliti mencoba untuk menerapkan type pembelajaran kooperatif yang menuntut seluruh peserta didik terlibat aktif disetiap tahapan yaitu tipe Numbered Head Together (NHT) . Dalam Numbered Head Together (NHT) peserta didik dibentuk kelompok, yang terdiri dari 4 peserta didik. Setiap anggota kelompok diberi nomor urut ( 1 ,
$2,3,4)$. Penomoran itulah yang menjadi kunci dan ciri type pembelajaran Numbered Head Together (NHT) . Dengan cara seperti ini diharapkan masing - masing peserta didik berkonsentrasi pada soal yang menjadi tanggung jawabnya sehingga peserta didik terlatih untuk mandiri dan bertanggung jawab penuh atas ketugasanya sesuai kesepakatan kelompok.

Type pembelajaran konvensional pada era sekarang ini diyakini kurang dapat memberikan kesempatan pada peserta didik untuk mengembangkan diri dan interaktif. Terlebih pada materi Fungsi Komposisi dan Fungsi Invers yang dianggap asing dan kurang menarik oleh peserta didik membuat peserta didik kurang terpacu untuk berkonsentrasi secara maksimal. Sebagian besar peserta didik lebih suka menunggu dan menyalin hasil presentasi temanya serta peserta didik kurang percaya diri. Type Numbered Head Together (NHT) selain belum pernah digunakan di SMK N 3 Yogyakarta penulis yakini dapat menjadi salah satu alternatif solusi permasalahan tersebut.

Dari identifikasi masalah di atas maka penelitian ini dibatasi pada masalah upaya meningkatkan konsentrasi dan hasil belajar dalam pembelajaran kompetensi Fungsi 
Peningkatan Konsentrasi dan Hasil Belajar Komposisi Fungsi dan Fungsi Invers dengan Pembelajaran Kooperatif Type Numbered Head Together (NHT) pada kelas XI TP 2

Nurlaila Mahmudah

Komposisi dan Fungsi Invers melalui penerapan pembelajaran kooperatif learning type Numbered Head Together (NHT) di kelas XI TP 2 SMK N 3 Yogyakarta.

Perumusan masalah dalam penelitian ini : 1) Bagaimanakah penerapan pembelajaran kooperatif learning type Numbered Head Together (NHT) di kelas XI TP 2 SMK N 3 Yogyakarta dapat meningkatkan konsentrasi dan hasil belajar peserta didik pada kompetensi Fungsi Komposisi dan Fungsi Invers? 2) Sejauh mana peningkatan konsentrasi belajar peserta didik dengan diterapkanya type pembelajaran kooperatif learning type Numbered Head Together (NHT) di kelas XI TP 2 SMK N 3 Yogyakarta pada kompetensi Fungsi Komposisi dan Fungsi Invers? 3) Sejauh mana peningkatan prestasi belajar peserta didik dapat dicapai dengan penerapan type pembelajaran kooperatif learning type Numbered Head Together (NHT) di kelas XI TP 2 SMK N 3 Yogyakarta pada kompetensi Fungsi Komposisi dan Fungsi Invers?

Penelitian ini bertujuan untuk : 1) Mendeskripsikan pelaksanaan pembelajaran yang mampu meningkatkan konsentrasi dan hasil belajar peserta didik dalam proses pembelajaran kompetensi Fungsi
Komposisi dan Fungsi Invers di kelas XI TP 2 SMK N 3 Yogyakarta melalui type Numbered Head Together (NHT)

2) Meningkatkan konsentrasi belajar peserta didik dengan diterapkanya type pembelajaran Numbered Head Together (NHT) pada kompetensi Fungsi Komposisi dan Fungsi Invers di kelas XI TP 2 SMK N 3 Yogyakarta. 3) Mengetahui besarnya peningkatan hasil belajar peserta didik dengan diterapkanya type pembelajaran Numbered Head Together (NHT) pada kompetensi Fungsi Komposisi dan Fungsi Invers di kelas XI TP 2 SMK N 3 Yogyakarta

Penelitian ini diharapkan dapat meningkatkan kompetensi guru khususnya dalam menyampaikan materi Fungsi Komposisi dan Fungsi Invers. Untuk siswa: peserta didik mampu mengatasi kesulitan dalam menyelesaikan soal - soal Fungsi Komposisi dan Fungsi Invers. Untuk sekolah : Dengan dilaksanakanya penelitian ini diharapkan ada peningkatan daya serap materi yang akan berdampak pada meningkatnya nilai rata - rata kelas mata pelajaran matematika selanjutnya akan dapat meningkatkan nilai rata - rata UAN untuk mata pelajaran matematika. 


\section{KAJIAN TEORI}

\section{Pembelajaran}

Pembelajaran merupakan suatu proses belajar dan mengajar dengan segala interaksi didalamnya. Pembelajaran merupakan suatu proses yang mengandung serangkaian perbuatan guru dan siswa atas dasar hubungan timbal balik yang berlangsung dalam situasi edukatif untuk mencapai tujuan tertentu (Moh. Uzer Usman, 2000 :4)

Berdasarkan definisi di atas dapat disimpulkan bahwa pembelajaran adalah suatu proses kegiatan komunikasi biinteraksi atau komunikasi dua arah antara pendidik dan peserta didik dimana peserta didik melakukan proses belajar secara terprogram dan mendapatkan hasil yang optimal.

\section{Pembelajaran Matematika}

Cobb (Erman Suherman , 2003 :

71) mendefinisikan pembelajaran matematika sebagai proses pembelajaran yang melibatkan siswa secara aktif dan konstruktif sehingga siswa mencoba menyelesaikan masalah yang ada dan mereka berpartisipasi aktif dalam pembelajaran matematika.

$\begin{array}{lcc}\text { Dari uraian di } & \text { atas dapat } \\ \text { disimpulkan bahwa } & \text { pembelajaran } \\ \text { matematika merupakan } & \text { suatu proses } \\ \text { yang mengandung } & \text { serangkaian }\end{array}$

perbuatan pendidik dan peserta didik dalam menelaah bentuk - bentuk atau struktur - struktur yang abstrak yang bertujuan mencapai suatu kompetensi yang ditetapkan.

\section{Konsentrasi Dalam Belajar}

Konsentrasi belajar yang baik dan maksimal dipercaya dapat membawa keberhasilan peserta didik dalam mencapai tujuan pembelajaran. Segala hal dapat direkam dan dapat dikeluarkan sewaktu dibutuhkan dengan jika konsentrasi juga baik.

Menurut Muhibbin Syah, (2005:136), seorang peserta didik yang menaruh minat besar terhadap matematika akan memusatkan perhatianya lebih banyak daripada peserta didik lain. Oleh karena pemusatan perhatian yang intensif terhadap materi itulah akan mendorong peserta didik belajar lebih giat dan semangat sehingga pada ahirnya dapat mencapai prestasi seperti yang diharapkan.

Beberapa hal yang penulis batasi pada kegiatan penelitian adalah upaya meningkatkan konsentrasi yang dikorelasikan dengan sikap peserta didik ini antara lain : 1) Rasaingin tahu, 2) Disiplin, 3) Optimis, 3) Teliti dan 4) Percaya diri. 
Peningkatan Konsentrasi dan Hasil Belajar Komposisi Fungsi dan Fungsi Invers dengan Pembelajaran Kooperatif Type Numbered Head Together (NHT) pada kelas XI TP 2

Nurlaila Mahmudah

Dari uraian di atas dapat disimpulkan bahwa peserta didik yang konsentrasinya baik ketika kegiatan pembelajaran dilaksanakan maka ia akan memiliki rasa keingintahuan yang tinggi, kedisiplinan dalam mengikuti penjelasan, optimis dalam mengikuti kegiatan diskusi maupun kegiatan lain sehingga menumbuhkan sikap, teliti dan percaya diri pada saat menyelesaikan semua tugas baik individu maupun tugas kelompok.

\section{Pembelajaran Kooperatif}

Menurut Kagan yang dikutip oleh Anita Lie (2002), Type kooperatif dimaknai dengan serangkaian aktivitas pembelajaran yang diorganisasikan sedemikian rupa sehingga pembelajaran difokuskan pada pertukaran informasi terstruktur antar pembelajar dalam suatu group yang bersifat sosial dan masing masing pembelajar bertanggung jawab penuh atas pembelajaran yang mereka jalani.

Dari uraian diatas dapat
disimpulkan bahwa pembelajaran
kooperatif pada dasarnya adalah type
pembelajaran yang sistematis dengan
pengelompokan peserta didik untuk
melaksanakan pembelajaran yang efektif
sehingga dapat memaksimalkan
kegiatan pembelajaran.

\section{Pembelajaran Kooperatif Type \\ Numbered Head Together (NHT)}

Menurut Muslim Ibrahim, (2000:28) pembelajaran kooperatif type Numbered Head Together (NHT) dilaksanakan melalui langkah - langkah pokok sebagai berikut :
a. Penomoran
b. Pendidik mengajukan tugas atau pertanyaan
c. Diskusi kelompok
d. Pendidik menyebutkan salah satu nomor anggota kelompok.

Salah satu keunggulan dari metude pembelajaran kooperatif type Numbered Head Together (NHT) adalah peserta didik menjadi lebih siap ketika disebut nama kelompok dan nomornya untuk mempresentasikan hasil diskusinya serta untuk menghindari kebiasaan saling melempar tanggung jawab dan tidak percaya diri. Pada kegiatan ini pemanggilan nama kelompok dan nomor dilakukan dengan pengundian, sehingga setiap saat peserta didik akan mempersiapkan diri menjadi wakil dari kelompok masing - masing untuk mempresentasikan hasil diskusinya.Dengan demikian, peserta didik akan berkonsentrasi penuh disetiap tahapan pembelajaran.

Berdasarkan hasil observasi di kelas XI TP 2 SMK N 3 Yogyakarta diperoleh kesimpulan sementara bahwa 
sebagian besar peserta didik kurang termotivasi, kurang berkonsentrasi dan bersikap pasif pada saat kegiatan pembelajaran berlangsung, jarang bertanya jika ada materi yang kurang bisa dipahami, lebih senang menunggu dan menyontek hasil temanya, cenderung ramai dan membicarakan masalah diluar materi baik pada saat pelaksanaan diskusi maupun saat presentasi kelompok.

Meskipun implementasi kurukulum 2013 yang menuntut setiap peserta didik berperan aktif dalam proses pembelajaran telah berjalan tiga tahun, akan tetapi tidak sedikit pendidik yang masih bingung bagaimana menerapkan type pembelajaran yang inovatif dan kreatif sehingga memudahkan peserta didik dalam berkonsentrasi dalam mengikuti setiap tahapan pembelajaran . Diakui atau tidak pada ahirnya pelaksanaan pembelajaran dilaksanakan secara konvensional dan membuat sebagian peserta didik cenderung bergantung pada teman satu kelompok yang dipandang lebih mampu untuk menyelesaikan setiap tugas kelompok, bersikap apatis dan lebih memilih untuk diam ataupun mengobrol sambil menunggu teman yang dirasa mampu menyelesaikan tugas kelompoknya, meskipun kelompok sudah dibentuk secara heterogen.
Penulis meyakini hal itu terjadi karena rendahnya tingkat konsentrasi peserta didik.

Berdasarkan kerangaka pikir di atas, maka hipotesis tindakan yang diajukan pada penelitian ini adalah penggunaan type pembelajaran Numbered Head Together (NHT) dapat meningkatkan konsentrasi dan hasil belajar peserta didik pada materi Fungsi Komposisi dan Fungsi Invers di kelas XI TP 2 SMK N 3 Yogyakarta.

\section{METODE PENELITIAN}

Penelitian dilaksanakan dengan mengambil lokasi di SMK Negeri 3 Yogyakarta, dengan alamat Jl.RW Monginsidi no 2A Yogyakarta. Lokasi penelitian tepatnya di Ruang 92 yang berada di lantai 2 menghadap ke selatan/jalan raya sehingga tidak jarang peserta didik terpancing keluar kelas secara tiba - tiba ketika ada pawai atau kampanye dan secara kebetulan belum terfasilitasi dengan fasilitas IT, sehingga mengharuskan pendidik berfikir keras bagaimana caranya menciptakan kegiatan pembelajaran yang tidak terkesan monoton dan dapat mengaktifkan peserta didik secara maksimal.

Penelitian dilaksanakan pada jam pembelajaran setiap hari sabtu dari jam pertama sampai jam ke empat sesuai dengan jadwal pelajaran yang ditetapkan 
Peningkatan Konsentrasi dan Hasil Belajar Komposisi Fungsi dan Fungsi Invers dengan Pembelajaran Kooperatif Type Numbered Head Together (NHT) pada kelas XI TP 2

Nurlaila Mahmudah

dimulai tanggal 12 sampai dengan tanggal 29 bulan September 2015. Pada saat penelitian dilaksanakan ada sedikit kendala alam yang kurang mendukung, karena pada sekitar jam 8 sd 9 sinar matahari yang masuk melalui jendela kaca dan tepat mengenai lajur tempat duduk peserta didik bagian utara. Selain terasa panas namun juga membuat silau mata peserta didik karena letak papan tulis mengharuskan peserta didik duduk menghadap ke timur, sehingga peserta didik harus menggeser posisi duduk ke bagian tengah dan menggeser posisi duduk peserta didik lajur lainya sehingga terkesan berjubel dan membuat peserta didik sedikit kurang nyaman serta kurang sedap dilihat.

Partisipan dari penelitian ini adalah peserta didik kelas XI TP 2 SMK N 3 Yogyakarta yang berjumlah 32 paserta didik yang kesemuanya berjenis kelamin laki - laki.

Penelitian ini merupakan Penelitian Tindakan Kelas (PTK ) yang bertujuan untuk meningkatkan konsentrasi peserta didik dalam proses pembelajaran materi peluang di dalam kelas melalui pembelajaran kooperatif type Numbered Head Together (NHT) SMK N 3 Yogyakartayang dilakukan oleh peneliti dengan dibantu seorang Kolaborator.
Prosedur penelitian terdiri atas dua siklus penelitian dengan mengikuti type yang dikembangkan oleh Kemmis dan Mc Taggart (1990: 14), yang selanjutnya oleh Suharsimi Arikunto(2005:16) dan Yoko Rimmy(2008:12) dijabarkan sebagai berikut :

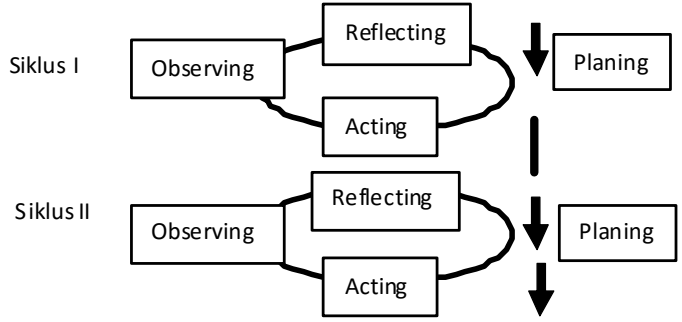

Gambar 1. Siklus dalam penelitian CAR type Kemmis dan Taggart

Rencana tindakan dilakukan dalam dua siklus, tiap siklus terdiri dari tahap perencanaan (planning), tindakan (action), observasi (observation) dan refleksi (reflection).

\section{Teknik Pengumpulan Data}

Pengumpulan data pada dilakukan dengan: 1) Observasi selama proses pembelajaran berlangsung untuk mengetahui konsentrasi belajar peserta didik pada saat pembelajaran dilaksanakan dengan menggunakan Type Numbered Head Together (NHT). 2) Kuisioner untuk mengetahui perlu tidaknya pelaksanaan pembelajaran menggunakan Type Numbered Head Together (NHT) . 3) 
Camera untuk mendokumentasikan fotofoto pada saat kegiatan pembelajaran berlangsung. 4) Test Evaluasi untuk mengetahui peningkatan prestasi belajar peserta didik pada mata pelajaran matematika kompetensi Fungsi Komposisi dan Fungsi Invers setelah diberi tindakan.

\section{Instrumen Penelitian}

Instrumen penelitian yang digunakan : 1) Lembar Observasi, 2) Kuisioner, 3) Dokumentasi, 4) Catatan Lapangan, 5) Tes

\section{Teknik dan Analisis Data}

Data kualitatif yang diperoleh dari hasil rekapitulasi pengisian angket diklasifikasikan berdasarkan aspek aspek yang dijadikan fokus analisis, sehingga diperoleh data seberapa besar kenaikan tingkat konsentrasi dan hasil belajar kompetensi Fungsi Komposisi dan Fungsi Invers dari peserta didik. Kemudian dikaitkan dengan data kuantitatif sebagai dasar untuk mendeskripsikan keberhasilan pelaksanaan pembelajaran menggunakan Type Kooperatif tipe Numbered Head Together (NHT) sebagai upaya meningkatkan konsentrasi dan hasil belajar matematika kompetensi Fungsi Komposisi dan Fungsi Invers bagi peserta didik.
Data Kuantitatif yang diperoleh dari hasil observasi diolah menggunakan deskriptif prosentase. Nilai hasil evaluasi yang didapat peserta didik dirata- rata untuk ditemukan keberhasilan individu dan klasikal sesuai dengan target yang ditetapkan. Data kuantitatif hasil penelitian diperoleh dengan rumus:

$\mathrm{T}=\frac{\text { Jumla h peserta didik yang melakukan indikator }}{\text { jumla } h \text { peserta didik }} \times 100 \%$

Konsentrasi peserta didik dalam satu kelas pada setiap siklus . Rumus penghitunganya adalah sebagai berikut : $\mathrm{X}=\frac{\sum \text { indikator konsentrasi baik }}{\text { jumlah peserta didik }} \times 100 \%$ Kualifikasi pencapaian konsentrasi sesuai dengan kriteria sebagai berikut : 1) $0 \leq \mathrm{T}<1,5$ masuk kriteria kurang, 2) 1,6 $\leq \mathrm{T}<2,5$ masuk kriteria cukup 3) $2,5 \leq \mathrm{T}<3,5$ masuk kriteria baik. 4) $3,6 \leq \mathrm{T} \leq 4$ masuk kriteria sangat baik

Hasil tes yang dilakukan diahir siklus I dihitung perolehan skor tiap peserta didik dan reratanya sedangkan melalui observasi dicatat aktivitas peserta didik berkaitan dengan rasa ingin tahu, disiplin, optimis, ketelitian serta rasa percaya diri untuk mengetahui besarnya konsentrasi belajar peserta didik, kemudian pada siklus selanjutnya dilakukan hal yang sama dengan memperbaiki setiap kelemahan pada siklus sebelumnya. Apabila terjadi 
Peningkatan Konsentrasi dan Hasil Belajar Komposisi Fungsi dan Fungsi Invers dengan Pembelajaran Kooperatif Type Numbered Head Together (NHT) pada kelas XI TP 2

Nurlaila Mahmudah

peningkatan maka diasumsikan bahwa pembelajaran dengan type Kooperatif tipe Numbered Head Together (NHT) dapat meningkatkan konsentrasi dan hasil belajar peserta didik.

\section{Indikator Keberhasilan}

Kegiatan penelitian dikatakan berhasil jika dicapai : 1) Konsentrasi belajar peserta didik pada saat pembelajaran yang meliputi: rasa ingin tahu, optimis, disiplin, teliti dan percaya diri, jika $100 \%$ peserta didik memperoleh skor rerata pada kriteria minimal Baik, 2) Persentase hasil belajar peserta didik dikatakan berhasil jika 75 $\%$ peserta didik mencapai Kriteria Ketuntasan Minimal (KKM) dengan batas pencapaian KKM 75 atau setara 2,6 pada skala empat, maka sklus dihentikan.

\section{HASIL PENELITIAN DAN PEMBAHASAN}

Sebelum kegiatan penelitian dilaksanakan, terlebih dahulu diawali dengan pengamatan di kelas XI TP 2 SMK N 3 Yogyakarta serta diskusi dengan Observer seputar permasalahan yang dihadapi peserta didik berkaitan dengan pembelajaran matematika.

Berdasarkan observasi pra tindakan dan diskusi dengan Observer diperoleh kesimpulan sementara bahwa pelaksanaan diskusi konvensional belum mampu mengaktifkan dan mengkondisikan peserta didik dengan optimal sehingga konsentrasi yang merupakan kunci sukses dalam setiap aktivitas belum seperti yang diharapkan. Seperti yang tergambar pada tabel hasil observasi pra tindakan berikut :

Tabel 1. Hasil observasi KONSENTRASI Pra Tindakan

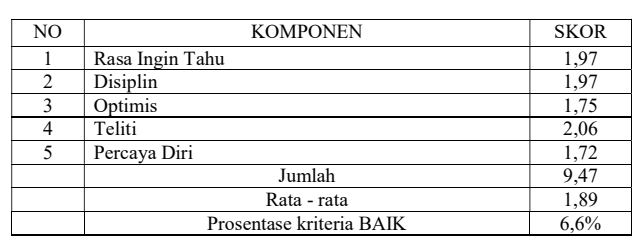

Dari tabel di atas terlihat bahwa konsentrasi peserta didik pada pra tindakan sangat rendah. Hanya 2 dari 32 peserta didik yang memiliki konsentrasi baik atau sebesar 6,6\%. Demikian juga dari hasil tes diagnostik selama 45 menit diperoleh hasil nilai tertinggi 100 , nilai terendah 44, rata- rata nilai 66 dengan pencapaian Kriteria Ketuntasan Minimal(KKM) sebesar 41\% .

Deskripsi Siklus

SIKLUS I

Perencanaan tindakan siklus I diawali dengan membuat rencana pelaksanaan pembelajaran (RPP) dan Lembar Aktivasi Siswa (LAS) , membuat soal tes ahir siklus I yang terdiri dari 5 butir soal uraian, membuat lembar observasi siklus I. serta mempersiapkan alat dan bahan yaitu 
Buku Siswa, spidol, kertas buram dan kamera.

Pengamatan yang lakukan oleh kolaborator pada siklus I meliputi Proses Belajar Mengajar (PBM), Rencana Pelaksanaan Pembelajaran (RPP) serta konsentrasi belajar peserta didik yang dikorelasikan pada sikap rasa ingin tahu, optimis, disiplin, teliti dan percaya diri.

Rerata hasil penilaian terhadap RPP sebesar 2,72 pada kualifikasi baik. Sedangkan rarata penilaian PBM sebesar 2,88 pada kualifikasi baik. Hal itu mengindikasikan bahwa dari unsur pendidik kesiapan melaksanakan kegiatan belajar mangajar tidak menemui kendala berarti. Namun demikian masih ada kendala pada indikator pengembangan dan penyajian hasil karya. Sebagian peserta didik masih terkesan belum termotivasi untuk mempresentasikan hasil diskusi kelompok dengan berbagai alasan. Kendala lain adalah pada indikator keterkaitan materi komposisi fungsi dengan permasalahan kontekstual terutama pada permasalahan yang berhubungan dengan masalah teknik pemesinan. Namun secara umum penilaiaan proses KBM dan RPP cukup mendukung untuk terciptanya proses pembelajaran yang kondusif bagi peserta didik dan keadaan ini diperbaiki pada siklus II.
Tabel 2. Hasil penilaian KONSENTRASI siklus I

\begin{tabular}{|c|c|c|}
\hline NO & KOMPONEN & SKOR \\
\hline 1 & Rasa Ingin Tahu & 2,66 \\
\hline 2 & Disiplin & 2,56 \\
\hline 3 & Optimis & 2,78 \\
\hline 4 & Teliti & 2,78 \\
\hline \multirow[t]{4}{*}{5} & Percaya Diri & 2,88 \\
\hline & Jumlah & 13,66 \\
\hline & Rata - rata & 2,73 \\
\hline & Prosentase kriteria BAIK & $72 \%$ \\
\hline
\end{tabular}

Dari tabel di atas terlihat bahwa setelah diberi tindakan dengan type yang berbeda dengan pada pra tindakan, pencapaian prosentase nilai baik pada indikator konsentrasi mengalami peningkatan secara keseluruhan. Rerata kelima indikator konsentrasi mengalami kenaikan meskipun belum terlalu signifikan terutama pada indikator disiplin. Beberapa peserta didik belum terbiasa dengan sintak type Numbered Head Together (NHT) dan masih terkesan mengulur - ulur waktu.

Refleksi siklus I

Beberapa catatan permasalahan yang berhasil dihimpun antara lain :

Dari rangkuman hasil observasi yang diperoleh hasil tentang rerata pencapaian indikator konsentrasi yang masih belum sesuai target karena dari 32 baru 24 peserta didik yang mencapai rerata baik atau setara dengan $75 \%$ dari rerata pada pra tindakan sebesar 6,6\%. Demikian juga dengan hasil tes ahir siklus. Meskipun sudah ada peningkatan jika dibandingkan dengan hasil tes sebelum tindakan namun masih belum signifikan, yakni dari rerata nilai 66 menjadi 67 dan 
Peningkatan Konsentrasi dan Hasil Belajar Komposisi Fungsi dan Fungsi Invers dengan Pembelajaran Kooperatif Type Numbered Head Together (NHT) pada kelas XI TP 2

Nurlaila Mahmudah

pencapaian ketuntasan minimal dari $41 \%$ menjadi $50 \%$, maka tindakan diteruskan pada siklus II.

Deskripsi Siklus II

Pada tahap perencanaan siklus II perangkat dan instrumen yang dipersiapkan tidak berbeda dengan siklus I yaitu : Membuat Rencana Pelaksanaan Pembelajaran (RPP), Lembar Kerja Siswa (LAS), lembar observasi keterlaksanaan pembelajaran, lembar observasi konsentrasi peserta didik serta lembar soal evaluasi ahir siklus II beserta pedoman pensekoranya serta memperbaiki beberapa kelemahan yang terjadi pada siklus I.

Implementasi Tindakan

Pengamatan pada siklus II tentang Proses Belajar Mengajar (PBM), Rencana Pelaksanaan Pembelajaran (RPP) serta konsentrasi belajar peserta didik yang mengalami perubaahan yang sangat signifikan. Rerata penilaian RPP sebesar 3,16 dan PBM sebesar 3,04. Beberapa perubahan dilakukan dalam penyusunan RPP pada siklus II, meskipun pada pemuatan fakta otentik masih belum maksimal. Hal ini terjadi karena karakter materi lebih banyak menekankan pada pengoperasian simbol komposisi, sehingga permasalahan kontekstual dan penggunaan media yg bervariasi sulit dilakukan .
Perubahan yang paling signifikan yang dicatat kolaborator pada siklus II teerjadi pada konsentrasi belajar peserta didik seperti yang ada tabel 3 berikut.

Tabel 3. Hasil penilaian KONSENTRASI siklus II

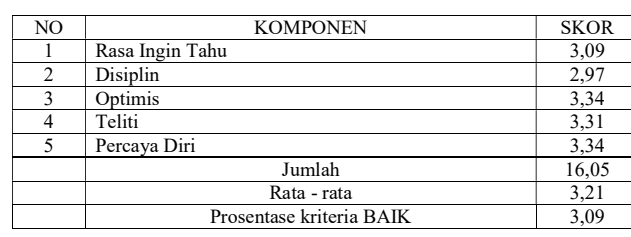

Pada tabel di atas rerata konsentrasi peserta didik menunjukkan kemajuan berada pada kualifikasi baik ambang batas atas.

Refleksi Siklus 2

Pada siklus II baik pendidik maupun peserta didik sudah tidak menemui kendala yang berarti. Baik pada perencanaan pembelajaran, proses KBM maupun pada konsentrasi peserta didik. Rasa senang dan gembira sangat terlihat pada mayoritas peserta didik, baik pada pelaksanaan diskusi, presentasi maupun tes diagnostik di ahir KBM.

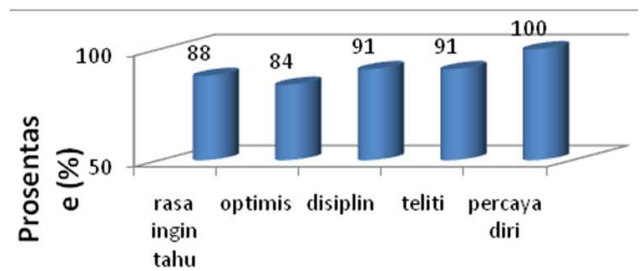

Grafik 1. Konsentrasi belajar siklus II

Dari grafik di atas dapat dilihat bahwa indikator konsentrasi peserta didik mencapai $100 \%$ skor baik diikuti 
dengan ketuntasan tes diagnostik di ahir siklus sebesar 91\%. Dapat disimpulkan bahwa konsentrasi belajar matematika peserta didik melalui type pembelajaran Numbered Head Together (NHT) yang dilaksanakan dengan dua silkus mengalami peningkatan yang signifikan sebagai implementasi pembelajaran saintifik seperti yang diamanatkan pada kurikulum 2013 dan siklus dihentikan.

\section{Pembahasan}

Tabel 4. REKAPITULASI KONSENTRASI PESERTA DIDIK

\begin{tabular}{|c|c|c|c|c|c|c|c|}
\hline NO & OBSERVASI & $\begin{array}{c}\text { RASA } \\
\text { INGIN } \\
\text { TAHU }\end{array}$ & OPTIMIS & DISIPLIN & TELITI & $\begin{array}{c}\text { PERCAYA } \\
\text { DIRI }\end{array}$ & $\begin{array}{c}\text { RATA- } \\
\text { RATA }\end{array}$ \\
\hline 1 & PRA TINDAKAN & 9 & 9 & 3 & 6 & 6 & 6,6 \\
\hline 2 & SIILLUI & 63 & 53 & 59 & 63 & 72 & 62 \\
\hline 3 & SIKLUS II & 88 & 84 & 91 & 91 & 100 & 90,8 \\
\hline
\end{tabular}

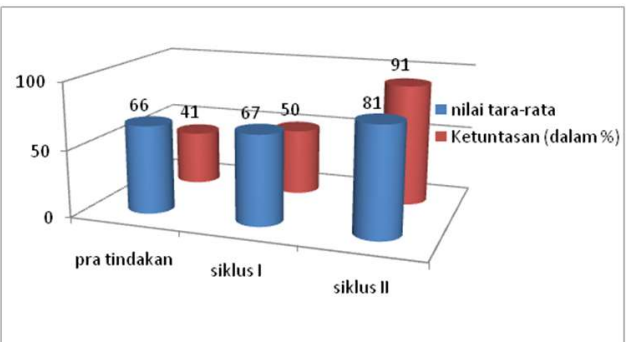

Grafik 2. Nilai rata - rata dan ketuntasan hasil tes diagnostik

\section{Hasil Pengisian Angket Responden}

Hasil pengisian angket responden dapat dilihat pada Tabel 5. Selain itu, terdapat beberapa masukan tentang penggunaan type Numbered Head Together (NHT) dalam pembelajaran matematika antara lain :

\section{a. Type Numbered Head Together (NHT) lanjut}

\section{b. Type Numbered Head Together (NHT) asik}

c. D11

Tabel 5. Hasil Pengisian Angket Responden / masukan Peserta Didik tentang type Numbered Head Together (NHT).

\begin{tabular}{|c|c|c|c|c|c|c|c|c|c|}
\hline \multirow{2}{*}{ NO } & \multirow{2}{*}{ PERTANYAAN } & \multicolumn{8}{|c|}{ FREKUENSI } \\
\hline & & 1 & $\%$ & 2 & $\%$ & 3 & $\%$ & 4 & $\%$ \\
\hline 1 & $\begin{array}{l}\text { Metode pembelajaran NHT } \\
\text { membuat saya termotivasi } \\
\text { untuk memperhatikan } \\
\text { penjelasan guru }\end{array}$ & 0 & $0 \%$ & 4 & $13 \%$ & 21 & $66 \%$ & 7 & $22 \%$ \\
\hline 2 & $\begin{array}{l}\text { Metode pembelajaran NHT } \\
\text { membuat saya lebih mudah } \\
\text { berkonsentrasi }\end{array}$ & 0 & $0 \%$ & 5 & $16 \%$ & 23 & $72 \%$ & 4 & $13 \%$ \\
\hline 3 & $\begin{array}{l}\text { Metode pembelajaran NHT } \\
\text { membuat saya berani untuk } \\
\text { bertanya dan menyampaikan } \\
\text { pendapat }\end{array}$ & 0 & $0 \%$ & 3 & $9 \%$ & 15 & $47 \%$ & 14 & $44 \%$ \\
\hline 4 & $\begin{array}{l}\text { Metode NHT melatih saya } \\
\text { untuk ta mpil dengan percaya } \\
\text { diri ketika presentasi di depan } \\
\text { kelas sebagai wakil dari } \\
\text { kelompok diskusi }\end{array}$ & 0 & $0 \%$ & 2 & $6 \%$ & 18 & $56 \%$ & 12 & $38 \%$ \\
\hline 5 & $\begin{array}{l}\text { Metode NHT melatih disiplin } \\
\text { untuk menjalin kerjasama } \\
\text { dengan sesama anggota } \\
\text { kelompok }\end{array}$ & 0 & $0 \%$ & 1 & $3 \%$ & 19 & $59 \%$ & 12 & $38 \%$ \\
\hline 6 & $\begin{array}{l}\text { Metode pembelajaran NHT } \\
\text { melath saya untuk lebih } \\
\text { bertanggung jawab untuk } \\
\text { merusaha memahami materi } \\
\text { dan mempresentasikan didepan } \\
\text { kelas sesuai kesepakatan hasil } \\
\text { diskusi kelompok }\end{array}$ & 0 & $0 \%$ & 3 & $9 \%$ & 21 & $66 \%$ & 8 & $25 \%$ \\
\hline 7 & $\begin{array}{l}\text { Metode pembelajaran NHT } \\
\text { membuat saya cepat bosan } \\
\text { dalam mengikuti pembelajaran }\end{array}$ & 17 & $53 \%$ & 14 & $44 \%$ & 1 & $3 \%$ & 0 & $0 \%$ \\
\hline 8 & $\begin{array}{l}\text { Metode pembelajaran NHT } \\
\text { membuat saya tidak terlibat } \\
\text { aktif dalam kelompok diskusi }\end{array}$ & 23 & $72 \%$ & 8 & $25 \%$ & 1 & $3 \%$ & 0 & $0 \%$ \\
\hline 9 & $\begin{array}{l}\text { Metode pembelajaran NHT } \\
\text { menciptakan situasi belajar } \\
\text { menjadi lebih menyenangkan } \\
\text { dan hidup }\end{array}$ & 0 & $0 \%$ & 4 & $13 \%$ & 21 & $66 \%$ & 7 & $22 \%$ \\
\hline 10 & $\begin{array}{l}\text { Metode pembelajaran NHT } \\
\text { membuat saya cermat teliti } \\
\text { berhati hati dal am mengerjakan } \\
\text { soal soal }\end{array}$ & 0 & $0 \%$ & 4 & $13 \%$ & 25 & $78 \%$ & 3 & $9 \%$ \\
\hline
\end{tabular}

Keterangan :

1: sangat tidak setuju

2 : tidak setuju

3 : setuju

4 : sangat setuju

Dari tabel rekapitulasi konsentrasi diatas sangat tampak bahwa pada setiap siklus mengalami kenaikan yang signifikan diiringi dengan kenaikan prosentase ketuntasan hasil tes diagnostik yang sangat signifikan pada ahir siklus II didukung dengan rekapitulasi tanggapan angket yang secara umum peserta didik setuju dan 
Peningkatan Konsentrasi dan Hasil Belajar Komposisi Fungsi dan Fungsi Invers dengan Pembelajaran Kooperatif Type Numbered Head Together (NHT) pada kelas XI TP 2

Nurlaila Mahmudah

senang dengan pembelajaran Kooperatif

type Numbered Head Together.

Oleh karena itulah maka dapat disimpulkan bahwa penerapan metode pembelajaran kooperatif type

Numbered Head Together di SMK N 3

Yogyakarta dapat meningkatkan konsentrasi dan hasil belajar peserta didik pada materi Fungsi Komposisi dan Fungsi Invers pada kelas XI TP 2 dan pada siklus II tindakan dihentikan.

\section{KESIMPULAN DAN SARAN}

Berdasarkan hasil penelitian tindakan yang dilakukan di kelas XI TP2 SMK N 3 Yogyakarta dapat disimpulkan bahwa pelaksanaan pembelajaran matematika melalui metode kooperatif type Numbered Head Together (NHT) sebagai upaya untuk meningkatkan konsentrasi dan hasil belajar peserta didik dilaksanakan melalui empat tahapan yaitu : 1) Penomoran. 2) Guru / Pendidik mengajukan tugas atau pertanyaan. 3) Diskusi kelompok. 4) Guru / Pendidik menyebutkan nomor identitas anggota

Penelitian dilakukan dengan 2 siklus,dan dari hasil penelitian melalui tindakan dan observasi dapat disimpulkan bahwa penerapan metode pembelajaran kooperatif type Numbered Head Together (NHT) dapat meningkatkan konsentrasi dan hasil belajar matematika peserta didik kelas XI TP 2 SMK N 3 Yogyakarta di tiap siklusnya.

Aspek - aspek konsentrasi yang diteliti meliputi : rasa ingin tahu peserta didik terhadap materi yang akan dipelajari, sikap optimis peserta didik pada saat melaksanakan tugas yang menjadi tanggung jawabnya, sikap disiplin peserta didik saat mengikuti kegiatan pembelajaran, sikap teliti dalam mengerjakan soal - soal dan memperhatikan pekerjaan teman serta sikap percaya diri pada saat peserta didik bertanya kepada teman ataupun menjawab pertanyaan teman. Untuk melatih konsentrasi dan rasa tanggung jawab peserta didik penugasan dilakukan dengan pengundian dan pemanggilan nomor identitas anggota untuk mewakili kelompok dalam mempresentasikan hasil diskusi kelompoknya. Melalui diskusi kelompok peserta didik dituntut aktif bertanya dan memahamkan bagi yang sudah mampu karena adanya kesadaran bahwa kesuksesan kelompok ditentukan oleh kesuksesan individu.

Perolehan data hasil observasi menunjukkan adanya kenaikan pencapaian tndikator konsentrasi peserta didik. Pada tahap pra tindakan pencapaian indikator konsentrasinya pada kriteria kurang sebesar 1,89 atau 
sebesar $6,6 \%$, pada siklus I rerata naik manjadi 2,73 dengan prosentase pencapaian kriteria baik mencapai 75\%, pada siklus II pencapaian indikator konsentrasinya naik lagi menjadi 3,21 atau mencapai100\%.

Kenaikan pencapaian indikator konsentrasi peserta didik juga diikuti meningkatnya nilai rata - rata dan ketuntasan tes diagnostic. Nilai rata rata peserta didik pada tes pra tindakan sebesar 66,44 dengan prosentase pencapaian KKM sebesar $41 \%$. Pada tes diagnostic ahir siklus I nilai rata rata peserta didik naik menjadi 66,53 dengan prosentase pencapaian KKM 50 $\%$. Tes diagnostic siklus II perolehan nilai rata - rata tes diagnostik peserta didik mengalami peningkatan kembali yaitu 80,50 dengan prosentase ketuntasan $100 \%$.

Hasil angket respon peserta didik juga menunjukkan respon yang positip dari peserta didik karena secara umum peserta didik mengaku senang dan termotivasi dengan pembelajaran type Numbered Head Together (NHT) sehingga pendidik berencana untuk melanjutkan penggunaan type

Numbered Head Together (NHT) pembelajaran materi selanjutnya.

Saran

Berdasarkan hasil penelitian tindakan kelas yang telah penulis laksanakan di kelas XI TP 2 SMK N 3

Yogyakarta, Penulis memberikan masukan dan saran untuk dipertimbangkan , bagi : 1)Peserta Didik, diharapkan agar peserta didik tidak alergi terhadap perubahan maupun hal baru yang belum pernah dijumpai karena selain untuk fariasi pembelajaran akan tetapi segala perubahan kearah lebih baik harus dicoba dan cari sisi positifnya sehingga peserta didik akan semakin kaya dengan inovasi dan kreatifitas khususnya dalam melaksanakan dan mengembangkan pengetahuan yang diperoleh dalam kegiatan pembelajaran. 2) Pihak Sekolah, Penulis berharap agar pembelajaran type Numbered Head

Together (NHT) menjadi salah satu alternatif type pembelajaran yang dilaksanakan di SMK N 3 Yogayakarta secara bergantian dengan type pembelajaran yang lain karena berdasarkan hasil penelitian, pembelajaran type Numbered Head Together (NHT) dapat meningkatkan konsentrasi dan hasil belajar matematika di kelas XI TP 2 , yang berdampak pada meningkatnya kompetensi peserta didik. 3) Peneliti lain Hasil penelitian ini hendaknya bisa dijadikan bahan referensi untuk pengembangan penelitian lebih lanjut. 
Peningkatan Konsentrasi dan Hasil Belajar Komposisi Fungsi dan Fungsi Invers dengan Pembelajaran Kooperatif Type Numbered Head Together (NHT) pada kelas XI TP 2

Nurlaila Mahmudah

\section{DAFTAR PUSTAKA}

Muhibbin Syah, (2000), Psikologi Pendidikan dengan Pendekatan Baru, Bandung: Remaja ,Rosdakarya.

Muslimin Ibrahim, (2000), Pembelajaran Kooperatif, Surabaya : Universitas Negeri Surabaya.

Handy Susanto,(2006). Meningkatkan Konsentrasi Siswa Melalui Optimalisasi Modalitas Belajar Siswa, Jakarta: Jurnal Pendidikan Penabur - No. 06/th

$$
\text { V/ } 2006
$$

Moh.Uzer Usman, (2000). Menjadi Guru Profesional, Bandung: Remaja Rodakarya.

Arikunto, Suharsimi, (2006), Penelitian Tindakan kelas. Jakarta : Bumi Aksara

Rimy Yoko. (2008). Penelitian Tindakan kelas sebagai Bentuk Pengembangan Profesi Guru. Yogyakarta. LPMP

Anita Lie, (2002). Mempraktikkan Cooperatif Learning di Ruang Ruang Kelas. Jakarta: PT Gramedia Widia Sarana Indonesia

Poerwadarminta, WJS. (1987). Kamus Umum Bahasa Indonesia. Jakarta : Balai Pustaka

\section{A.Sarjana, 2007.PMRI Sangat Mempermudah Belajar Matematika. Kumpulan Makalah.Tidak diterbitkan.}

Sumaryanta. Pembaharuan Pembelajaran. Kumpulan Makalah. Tidak diterbitkan.
Rusgianto H.S.Kurikulum Tingkat

Satuan Pendidikan. Kumpulan Makalah.

Tidak diterbitkan.

Dimyati dan Mudjiono,2009. Belajar dan Pembelajaran,Rineka Cipta.

Arends, Ricard I, (2004). Learning to Teach(sixth edition). Boston: Mc Graw Hill

Erman Suherman, Turnudi, Didi Suryadi, Tatang Herman, Suhendra, Sufyani,Prabawanto, Nurjanah, Ade Nurhayati, (2003). Srategi Pembelajaran Kontemporer (Edisi Revisi). Bandung: JICA.

Utami Munandar, C.S. (1992). Mengembangkan Bakat dan Kreativitas Anak Sekolah, Jakarta: Gramedia 